\title{
Ca-metasomatism of lawsonite eclogite-facies metasediment evidences high-pressure intra-slab C-O-H-S fluid transfer
}

\author{
ANTONIN T. LAURENT, ADÉLIE DELACOUR AND JUNE \\ CHEVET
}

Université de Lyon, UJM-Saint-Etienne, CNRS, ENS-Lyon, UCBL, LGL-TPE UMR 5276

Presenting Author: antonin.laurent@univ-st-etienne.fr

Subduction and recycling of the hydrated upper oceanic crust and the overlying sediments into the mantle has the potential to change mantle composition in terms of volatile contents (e.g. S, F, $\mathrm{H} 2 \mathrm{O}$ ). Mantle enrichments in turn is responsible for the more oxidized and volatile-rich nature of the magmas generated above subduction zones, compared to the mid-ocean ridge basalts. While the consequences of mantle enrichment are well documented, the metamorphic processes governing fluid release from metasediments and subsequent interaction between the fluid and ultramafic lithologies are still under debate.

Hectometric shear zones preserving eclogite facies metasediments embedded in a soft serpentinite matrix are frequent in fossil ophiolites. The strong chemical and rheological contrast between calcareous sediments and serpentinites may lead to the development of a high-pressure Ca-rich metasomatic rind reflecting high-pressure fluid release and interaction. In the Monviso ophiolite (Western Alps), decametric boudins of calcareous metasediments embedded in (meta-)serpentinite and talc-schists preserve eclogite-facies paragenesis consisting of garnet-lawsonite-chloritoid $+/-$ talc. Preliminary phase equilibria modelling in the $\mathrm{CaO}-\mathrm{FeO}-$ $\mathrm{MgO}-\mathrm{Al}_{2} \mathrm{O}_{3}-\mathrm{SiO}_{2}-\mathrm{H}_{2} \mathrm{O}-\mathrm{O}_{2}$ system indicates an equilibrium pressure higher than $2.1 \mathrm{GPa}$ at $500^{\circ} \mathrm{C}$ under moderately oxidizing conditions. Toward the rim of the metasediment boudin, lawsonite is progressively pseudomorphosed by zoisite/clinozoisite with minor talc and white micas. The lawsonite-out reaction is associated with dehydration monitored by a drop in measured whole-rock LOI from 6-7 wt \% down to $2.5 \mathrm{wt} \%$, corresponding roughly to lawsonite and zoisite/clinozoisite water content, respectively. Systematic variation in volatile elements $(\mathrm{Be}, \mathrm{Cl}, \mathrm{F}, \mathrm{C}$, S) across the metasomatic front highlights the influence of white micas, lawsonite, sulphate/sulphide and carbonate stability as a function of $\mathrm{P}-\mathrm{T}$ and $\mathrm{H} 2 \mathrm{O}-\mathrm{CO} 2-\mathrm{O} 2$ availability. Whole-rock $\mathrm{C}$ and $\mathrm{S}$ isotope compositions confirms significant mass transfer from the sediments to the 